\title{
EPA'S ORGANIZATIONAL STRUCTURE
}

\author{
Alfred A. Marcus*
}

\section{INTRODUCTION}

The business historian Alfred Chandler holds that the structure of an organization has a significant effect on the policies it pursues. ${ }^{1}$ This article reviews the origins and early history of the Environmental Protection Agency ("EPA"), and examines the following question: had EPA been structured differently, would it have pursued different policies? With the benefit of hindsight, it is tempting to criticize EPA for assuming the form that it did. The United States may have had better natural resource and environmental protection policies if some of the principles of comprehensive environmental management ("CEM") considered at EPA's birth had been followed. This article explains why these principles were not consistently carried out.

The article is organized as follows. It first sets forth the principles of CEM as articulated by influential writers and thinkers at the time of EPA's organization in 1970. Second, it discusses how these principles affected the staff group that created EPA and had primary responsibility for designing the agency-the staff of the Ash Council. Third, it focuses on how these principles were used to forge EPA's internal structure, that is, the extent to which they were used to organize the agency according to the so-called "functional" model that was under discussion at the time. Fourth, the article explains how the principles of CEM affected EPA's staff in carrying out its dayto-day activities. Finally, the article gives some reasons for the imperfect realization of CEM principles and speculates about the consequences for environmental and natural resource policy of such imperfect realization.

The Principles of Comprehensive Environmental Management

The principles of CEM that influenced EPA during its organizational stage came from a number of sources. The following describes the different versions of CEM as expressed in the ecology, economics, and political science literature of the time.

Copyright $\odot 1991$ by Law and Contemporary Problems

- Associate Professor, University of Minnesota and Carlson School of Management, Strategic Management Department.

1. Alfred D. Chandler, Jr., Strategy and Structure 3 (MIT Press, 1962). 


\section{A. CEM in the Ecology Literature}

The history of the environmental movement can be divided into three stages: conservation, public health, and natural beauty. ${ }^{2}$ The conservation stage was directed mainly at land-use problems, wilderness preservation, and the exploration of resources such as forests and waterways. During this stage environmentalists viewed issues in isolation from one another. The next stage, public health, led to a concentration on pathogenic organisms. Aesthetic considerations generally were ignored while attention was directed to the links between environmental conditions and chronic diseases. The 1960 s concern for natural beauty started a trend toward a "holistic" or "comprehensive view" of environmental problems. ${ }^{3}$ The goals of the environmentalists moved toward realizing ecological precepts like the "balance of nature" and a "steady state" environment. 4 Environmentalists hoped to achieve environmental stability, or some type of continuing process of dynamic homeostasis and self-renewal. In order to illustrate these concepts, they employed the metaphor "spaceship earth." The earth was seen as a unified system dependent upon its interrelating parts. As a spaceship, it had surpluses, redundancy, and back-up capacity, but a limited carrying capacity which required that people recycle and re-use resources to the extent feasible. ${ }^{5}$

\section{B. CEM in the Economics Literature}

At the time of EPA's organization, economists focused on the flow of materials from the environment to the economy and the return flow of these materials to the environment as wastes or residuals. ${ }^{6}$ They developed the materials balance model, under which, if there were no "inventory accumulation," the mass of residuals returning to the environment had to equal the mass of basic fuels, gases, foods, minerals, and other raw materials leaving the environment and entering the economic system. ${ }^{7}$ The comprehensive view provided by this model made it impossible to take a narrow view of pollution. Air, water, and soil pollution could not be seen as separate, unrelated problems. ${ }^{8}$ Moreover, it was impossible for humans to isolate the impact of their actions on the environment. Human economic actions had multiple effects, some good and some bad. Careful analysis and

2. Lynton K. Caldwell, Environment: A Challenge for Modern Society 33-50 (Natural History Press, 1970).

3. Id at 67

4. Id at 72 .

5. Id at 80-87. See also Lynton K. Caldwell, Man and His Environment: Policy and Administration 14-18 (Harper \& Row, 1975).

6. A. Myrick Freeman III, Robert H. Haveman \& Allen V. Kneese, The Economics of Environmental Policy 33 (John Wiley \& Sons, 1973).

7. Id at 11-19. "Accumulation of inventory" means stocks of plants, equipment, consumer durables, residual buildings, and other goods. See id at 13 .

8. Id at $31-32$. 
expertise were needed to trace the effects and ramifications of economic activities and to judge their net impact. ${ }^{9}$

Economists presented four options for controlling pollution. Society could: (1) reduce the amount of materials and energy used in economic activity; (2) treat waste products in order to make them less harmful to the environment; (3) choose the time and place of the discharge of waste products in order to minimize their damage; or (4) augment the environment's waste assimilative capacities through investment. ${ }^{10}$

\section{CEM in the Political Science Literature}

During EPA's organizational period, political scientists criticized existing pollution control programs as being too fragmented and decentralized to accomplish the goals that ecologists and economists advocated." Dispersion of power over pollution control prevented decisive action and hindered comprehensive or radical alterations of policy. Changes in environmental policy were too incremental. Public or private groups that were either opposed to the alterations or were threatened by resulting alterations of the power structure blocked policy changes. ${ }^{12}$ Political scientists felt that authority should be concentrated in a single national agency that would coordinate fragmented environmental programs and take a broad view of environmental problems. ${ }^{13}$ The political scientists thought that during the late 1960s the government lacked both the appropriate organization and the necessary authority to deal with environmental degradation.

\section{Analysis of the Diverse Concepts of CEM}

The CEM concepts reflected in these writings took into account ecological arguments advocating steady-state equilibrium, economic arguments advocating monitoring the movement of all materials into and out of the environment, and political arguments advocating rapid policy innovation. Ecologists believed that nature deserved ultimate respect and thus the environment should be managed as a whole. ${ }^{14}$ Since, in their view, everything was inter-connected, the ecologists called for systematic examination of the impact of human activities on nature. To this end, CEM aimed to evaluate national growth policies, because GNP, the traditional means of assessing growth, did not fully measure all components of growth. For instance, GNP did not adequately account for aesthetic values and collective enjoyments, nor did it take into account natural processes (for example, damage to species

\footnotetext{
9. Id at 128 .

10. Id at 25-31.

11. David F. Paulsen \& Robert B. Denhardt, eds, Pollution and Public Policy (Dodd, Mead \& Co, 1973).

12. Walter A. Rosenbaum, The Politics of Environmental Concern 95 (Praeger, 1973).

13. Id at 108 .

14. S. Dillon Ripley \& Helmut K. Brechner, Ecosystem Science as a Point of Synthesis, in Roger Revelle \& Hans H. Landsberg, eds, America's Changing Environment 20-31 (Beacon Press, 1967).
} 
regardless of whether the processes creating the damage were useful to humans).

Economists did not question the primacy of growth. ${ }^{15}$ For them, CEM concerned the existence of market defects. The relationship between human activity and the natural world had to be understood as a system in which nature provided the inputs to economic activity and absorbed the outputs after economic activity had taken place-after raw materials had been extracted, transformed into useful products, and consumed. The price system was not fully efficient in reflecting this system because it did not adequately account for the costs of externalities, such as damage to the air and water and losses in the value of nature's inputs to future generations. In order for the system to be efficient, externalities had to be internalized through taxes and user charges. With the "true costs" of production reflected in the price system, there would be a greater incentive to use less of a nonrenewable or polluting resource, to conserve, or to find substitutes, alternatives, or replacements. ${ }^{16}$

Consumer activists, like those associated with Ralph Nader, considered the political argument to be paramount. CEM was one way to concentrate government authority and upgrade programs that in the past had been accorded low status. Nader reports denounced existing air and water pollution control programs, maintaining that the bureaucracy had not been sufficiently active in implementing laws passed by Congress. ${ }^{17}$ Senator Edmund Muskie, a Democrat from Maine, a presidential contender, and an environmental proponent whom the Nader groups criticized, admitted that the "administration of federal programs did not match the gravity of the problems." 18 The House Committee on Interstate and Foreign Commerce held hearings to investigate organizational problems. ${ }^{19}$ Witnesses testified that pollution control did not have a high enough priority. The National Air Pollution Control Administration ("NAPCA") was "buried" in the Department of Health, Education, and Welfare ("HEW"). Similarly, the Federal Water Pollution Control Administration ("FWPCA") was found at the bottom level of the Department of Interior. Both NAPCA and FWPCA suffered from frequent reorganization, bureaucratic layering, distance from the secretary, and strong competition for limited resources from other growing agencies.

15. See, for example, Allen V. Kneese, Robert U. Ayres \& Ralph C. D'Arge, Economics and the Environment: A Materials Balance Approach 9 (Resources for the Future, 1970).

16. Allen V. Kneese, Analysis of Environmental Pollution, in Robert Dorfman \& Nancy Dorfman, eds, Economics of the Environment 39-42 (W. W. Norton, 1972); see also Larry E. Ruff, The Economic Common Sense of Pollution, in Dorfman \& Dorfman, Economics of the Environment 13-15 (cited in this note).

17. John C. Esposito, Vanishing Air 259-98 (Grossman, 1970); David Zwick \& Marcy Benstock, Water Wasteland 152-82 (Grossman, 1971).

18. Charles O. Jones, Clean Air: The Policies and Politics of Pollution Control 175 (U Pittsburgh Press, 1975).

19. Hearings on Air Pollution Control and Solid Wastes Recycling before the Subcommittee on Public Health and Welfare of the House Committee on Interstate and Foreign Commerce, 9lst Cong, 1st \& 2d Sess (1969-1970). 
A concern for the administration of pollution control programs also motivated White House staff to favor program consolidation. ${ }^{20}$ The reasons for consolidation differed between consumer activists and Congress, on the one hand, and the White House, on the other. Consumer activists and Congress sought greater enforcement powers and regulatory authority for a range of disparate programs covering diverse media, such as air, water, soil, and pesticides. In contrast, the White House staff believed that a more systematic approach to environmental problems-an approach that would consider alternative policies and establish priorities-would give the executive branch greater control. Business leaders also expressed displeasure with the existing system. Instead of diverse regulatory programs administered by separate layers in the bureaucracy and interpreted differently in regional and state settings, they sought a single focal point for setting standards and implementing environmental laws. A 1970 poll conducted for Fortune magazine showed that 53 percent of business executives favored a single national agency to establish standards. ${ }^{21}$

\section{E. The President's Message}

Although intentions differed among the various parties that proposed creating a new environmental agency, support for such an agency from all quarters was high. Because of this broad support, President Nixon, in his 1970 "Message on the Environment," could afford to be clear about the need for reorganization:

To meet future needs, many organizational changes will . . be needed. Federal institutions for dealing with the environment and natural resources have developed piecemeal over the years in response to specific needs, not all of which were originally perceived in the light of the concerns we recognize today. Many of their missions appear to overlap, and even to conflict. ${ }^{22}$

The President asked the Ash Council to study the organization of federal environmental, natural resource, and oceanographic programs. ${ }^{23}$

III

\section{The Formation Process}

\section{A. The Ash Council}

The president invariably delegates to a staff group the authority to prepare a proposal for the reorganization of an agency or program. In the case of Reorganization Plan Number 3 that created the Environmental Protection Agency, President Nixon delegated this authority to the staff of the Ash

20. Council on Environmental Quality, Environmental Quality: The First Annual Report of the Council on Environmental Quality 233 (US Govt Printing Office, 1970) ("CEQ, The First Annual Report").

21. See Robert S. Diamond, What Business Thinks, Fortune 118 (Feb 1970).

22. The President's Message on the Environment, February 10, 1970, reprinted in CEQ The First Annual Report at 254, 270 (cited in note 20).

23. Id. 
Council. ${ }^{24}$ In order to understand the reasons for creating EPA, it is necessary to examine the motivations of this staff group and the factors that influenced its deliberations. Like the creators of the War on Poverty, the designers of EPA can be characterized as professional reformers. They displayed an independence of judgment and tried to maintain relative immunity from outside criticism. ${ }^{25}$ They were also attracted to esoteric ideas and to advanced concepts in economics and ecology, such as residuals management. However, the staff of the Ash Council could not achieve independence from contrary political pressures. ${ }^{26}$

The politics involved in the reorganization process tempered the values and ideas that were then influencing the Ash Council staff in its design of EPA. ${ }^{27}$ For example, the staff believed that the wastes of an affluent society should be comprehensively managed and that environmentalists should be represented by a department or agency in the federal structure. Moreover, the belief that pollution problems would probably worsen over time influenced the council's deliberations. In order both to cope with existing pollution problems and to anticipate future problems, the staff advocated consolidating pollution control programs in a separate department. This recommendation had to overcome various objections, however, before the President agreed to create EPA.

Opposing political actors who criticized creating a separate pollution control department offered counter-proposals of their own. A Domestic Council task force suggested that the Ash Council design a new department of natural resources, ${ }^{28}$ while Senators Hugh Scott and Edmund Muskie introduced bills to create an independent environmental protection administration. ${ }^{29}$ The Ash Council staff was divided over which proposal it should recommend to the President. Should it propose a large department with a broad environmental quality mission or should it call for a smaller

24. Daniel P. Moynihan, Maximum Feasible Misunderstanding 21-37 (The Free Press, 1970).

25. Message of the President Relative to Reorganization Plans Nos 3-4 of 1970, July 9, 1970 , cited in CEQ The First Annual Report 294-305 (cited in note 20); Message of the President Transmitting Reorganization Plan No 3 of 1970, July 9, 1970, in CEQ The First Annual Report 306-07 (cited in note 20).

26. See Kneese, Ayres \& D'Arge, Economics and the Environment at 29 (cited in note 15).

27. Shortly after President Nixon took office in January 1969, he appointed Roy Ash, a former Lition Industries executive, to head the President's Advisory Council on Executive Organization ("PACEO"). Serving with Ash on the Council were Frederick R. Kappel, former chairman of the board of AT\&T; Walter N. Thayer, president of Whitney Communications Corporation; Richard M. Paget, president of the management consulting firm Cresap, McCormick, and Paget; Dr. George P. Baker, retiring dean of the Harvard Business School; and the Honorable John B. Connally, former governor of Texas and practicing lawyer. While Ash played an active role in the proceedings that led to the proposal to establish EPA, the other council members did not. They functioned as an absentee board of directors. The previous reorganization Plan Number 2, developed by the Ash Council prior to its work on environmental programs, changed the Bureau of the Budget into the Office of Management and the Budget ("OMB") and created the Domestic Council in the Executive Office. Gregory Mills, Design for Environmental Protection 1 (JFK School of Govt, 1974) (C16-74-026).

28. Alfred A. Marcus, Promise and Performance 32 (Greenwood Press, 1980). The domestic council was a White House unit led in 1969 by John Erlichman.

29. Alfred A. Marcus, What Does Reorganization Accomplish: The Case of the EPA 16 (unpublished PhD dissertation, Harvard U, 1970). 
bureaucratic entity with a specific pollution control focus? Both the staff coordinator, Amory Bradford, and Roy Ash initially favored creating a department that would combine natural resources and pollution control functions, but they did so for different reasons. While Bradford thought that a large department could formulate and carry out a balanced growth policy, Ash thought that the secretary of a large department that would handle competing interests would be more loyal to the White House than to the department's constituencies. ${ }^{30}$ Before the Ash Council sent its final proposal to the President, it consulted the heads of the affected existing departments who were reluctant to give up the personnel, resources, and authority that a new environmental organization would need. In response to this persistent reluctance, the President modified the final proposals sent to him by the Ash Council. ${ }^{31}$

The Ash Council staff had to steer the plan to create EPA through this complex political obstacle course. The process of reaching agreement produced a more modest reorganization plan than the one originally called for by the Domestic Council task force. Natural resource and pollution control functions were not combined in a large department with a broad environmental quality mission. The following account of EPA's origins traces how the decision was made to focus EPA's mission on pollution control.

\section{B. Opposing Suggestions}

A Domestic Council task force led by John Whittaker was organized to prepare the President's "Message on the Environment," which he delivered in February 1970.32 In November 1969, while preparing the presidential address, the task force advised the Ash Council that environmental protection and natural resource programs should be top priority targets for reorganization. The task force recommended that the Ash Council consider creating a new Department of Natural Resources. ${ }^{33}$ The task force noted that, for more than fifty years, various administrations had studied and advocated creating a Department of Natural Resources but that congressional committees, government bureaus, and special interest groups had not supported such a new department. Previous suggestions to amalgamate natural resource programs had come from Gifford Pinchot and his followers. ${ }^{34}$ In contrast to John Muir, founder of the Sierra Club, the Pinchot group had not been primarily concerned with the preservation of natural conditions for aesthetic purposes; rather, the group was concerned with the

30. Marcus, Promise and Performance at 32 (cited in note 28).

31. Id at 18-23. See note 59 and accompanying text.

32. CEQ The First Annual Report at 254-71 (cited in note 20). Serving on this task force were government lawyers John Quarles and Roger Starlow, scientist John Buckley, and OMB Budget Examiner Al Alm-all of whom later became leading executives in EPA.

33. Marcus, Promise and Performance at 32 (cited in note 28).

34. See Gifford Pinchot, The Birth of Conservation, in Roderick Nash, ed, The American Environment 39-42 (Addison Wesley, 1968). 
sparing and economical use of natural resources for economic development. ${ }^{35}$ However, a new interest in environmental quality transcended the old conservationist debate between preservationists and developers. The Domestic Council task force's suggestion for reorganization was inspired by a view of humans as space voyagers on spaceship earth, ${ }^{36}$ which emphasized preserving the eco-balance and decontaminating an already polluted environment. According to the task force, the increased public support for enhancing environmental quality gave the Ash Council an opportunity to overcome the ordinary resistance to reorganization found in committees, bureaus, and special interest groups. ${ }^{37}$

Senator Muskie's Subcommittee on Air and Water Pollution considered revising existing air and water pollution laws and held hearings for that purpose. However, even with this legislative activity, the task force's efforts to design a new department did not take into account existing or proposed environmental legislation because complete review of all laws dealing with the environment was not possible in the short period of time allotted. ${ }^{38}$ Moreuver, the job of examining environmental legislation had been reserved for the Environmental Quality Council in the White House. ${ }^{39}$ Thus warned to keep its distance from the legislative branch, the Ash Council was constrained from doing an extensive review of existing environmental statutes. The Ash Council designed a bureaucracy to fit the changing conception of the environmental problem, not one that would be an effective instrument for implementing existing laws.

Members of Congress were not directly involved in the Ash Council's deliberations. However, bipartisan support existed in the Senate for some type of environmental protection administration. In February 1970, the Republicans, led by Senator Hugh Scott, introduced a bill to establish an agency with an administrator and three deputy administrators. ${ }^{40}$ In April 1970, the Democrats, led by Senator Muskie, introduced a similar bill to establish an agency with an administrator and five deputies. ${ }^{41}$ 34).

35. Id; John Muir, $A$ Voice for Wilderness, in Nash, ed, The American Environment 71-74 (cited in note

36. For readings on this development, see Carol Purcell, ed, From Conservation to Ecology (Crowell, 1973); Roderick Nash, ed, Environment and Americans (Holt, Rinehart \& Winston, 1972).

37. See J. Clarence Davies III \& Barbara S. Davies, The Politics of Pollution 107-08 (Bobbs Merrill, $2 \mathrm{~d}$ ed 1975). The chapter on public opinion relates how quickly pollution control had become a major concern. In 1967 most citizens considered it among the least important issues, while in 1970 it was ranked second only to crime. More than $50 \%$ of those polled mentioned that they were worried about deteriorating air and water quality. Id at 80-102.

38. Marcus, What Does Reorganization Accomplish at 19 (cited in note 29).

39. The Environmental Quality Council was very short-lived. In an effort to head off the National Environmental Policy Act of 1969 which set up the Council on Environmental Quality ("CEQ") in the White House, Nixon established his own environmental council. Nixon, however, learned to live with CEQ, and the Environmental Quality Council soon was disbanded. See also notes $45-46$.

40. S 3388, 91 st Cong, 2d Sess (Feb 4, 1970).

41. S 3677, 91 st Cong, 2d Sess (April 6, 1970). Representative Wydler in the House (HR 16363, 91 st Cong, 2d Sess (March 9, 1970) also introduced a bill calling for an environmental protection agency. His agency did not include sewer grant or pesticides authority. 
Senators Scott and Muskie favored creating an independent agency designed primarily to deal with pollution problems. At the same time, the Domestic Council task force informed the Ash Council that it would be most interested in a proposal to create a new Department of Natural Resources with a broad environmental quality mission. The question remained whether the Ash Council would move toward the broader goal of environmental quality as the task force suggested or toward the more limited notion of a separate agency that the senators favored.

\section{Bradford, the Environmental Protection Group, and Ash}

Former New York Times executive Amory Bradford, the Ash Council staff coordinator, was committed to holistic thinking and the broad goal of environmental quality. He favored establishing a Department of the Environment and Natural Resources that would combine the related functions of managing energy, mineral, and renewable resources and environmental protection. ${ }^{42}$ According to Bradford, such a department was consistent with the need for a balanced growth policy and with the goals of the National Environmental Policy Act of 1969 ("NEPA"). ${ }^{43}$ It would also carry out the President's proposal that "the nation develop a national growth policy." 44 The activities of the new department would conform to the dictates of Section 101 (a) of NEPA:

to create and maintain conditions under which man and nature can exist in productive harmony, and fulfill the social, economic, and other requirements of present and future generations of Americans. ${ }^{45}$

The new department that Bradford favored would work closely with the Council on Environmental Quality ("CEQ") 46 to develop a growth policy that did not abandon the goal of industrial expansion but changed the emphasis from growth at any price to a policy more in harmony with the needs of the ecosystem. ${ }^{47}$

42. Marcus, What Does Reorganization Accomplish at 20 (cited in note 29).

43. National Environmental Policy Act of 1969, Pub L No 91-190, 83 Stat 852 (1970), codified at 42 USC $\S 4331$. NEPA is reprinted in CEQ The First Annual Report at 243-49 (cited in note 20).

44. Excerpt from the President's State of the Union Address, in CEQ The First Annual Report at 252 (cited in note 20 ).

45. National Environmental Policy Act of 1969 \$101(a), 83 Stat at 852, reprinted in CEQ The First Annual Report at 244 (cited in note 20).

46. NEPA, signed into law by President Nixon on January 1, 1970, created CEQ in the Executive Office of the President. CEQ was supposed to help the President prepare an annual environmental quality report and establish national policies for improving environmental quality. NEPA required that all federal actions that significantly affected the environment have environmental impact statements; CEQ administered this process.

47. The holistic view held by Bradford was not entirely new. The difference between previous attempts to manage the environment comprehensively and Bradford's proposal was that Bradford used ecological concepts to justify the need for a national growth policy. The first application of comprehensive environmental management to natural resource and environmental programs occurred during the New Deal under the Natural Resources Planning Board. Later, in 1948, the Hoover Commission called for a reorganization of the Interior Department to achieve comprehensive management. And, more recently, the Program Planning Budgeting System ("PPBS") introduced by Lyndon Johnson was designed to produce similar comprehensive management for all government programs. See Richard Polenberg, The New Deal and Administrative 
Bradford's desire for comprehensiveness was shared by most of the experts the Ash Council consulted. In February 1970, the Ash Council received special assistance from a group of academics convened by the environmental think-tank Resources for the Future ("RFF"). ${ }^{48}$ It consulted RFF scholars Hans Landsberg, Edwin Haefele, and Allan Kneese, all of whom had outstanding reputations for innovative studies in the natural resource and environmental fields. ${ }^{49}$ The staff also interviewed private consultants and other experts in universities.

This expert advice affected the organization of the Ash Council's staff. Bradford applied the principles of ecology when he divided his aides into three groups: the Energy and Mineral Resources Group, the Renewable Resources Group, and the Environmental Protection Group. Ecology demanded systems thinking instead of ordinary Cartesian logic. ${ }^{50}$ Instead of examining the simple cause and effect relationships between discrete entities, ecologists examined the complex connections between living and nonliving matter needed to sustain the ecosystem. The Energy and Minerals Group concentrated on government programs dealing with power production, water supply, and substances mined from the soil. The Renewable Resources Group focused on programs for agriculture, forests, wildlife, and fish. And the Environmental Protection Group was responsible for waste disposal and pollution control activities. The five staff members who served on the Environmental Protection Group were full-time Ash Council employees Douglas Costle, Victoria Pohle, and Eric Rubin; a White House Fellow in the Department of Health, Education, and Welfare ("HEW"), Wilson Talley; and Princeton political science Professor J. Clarence Davies. ${ }^{51}$

Reform and Keith Henderson, Federal Administrative Reorganization, both in Frank Evans \& Harold Pinkett, eds, Research in the Administration of Public Policy 97-115 (Harvard U Press, 1975).

48. Resources for the Future was created by the Ford Foundation in the early 1950s. In 1953 it organized the Mid-Century Conference on Resources for the Future, the first major national conservation conference since Teddy Roosevelt and Gifford Pinchot staged the National Governors Conference in 1908. See Katherine Barkley \& Steve Weissman, The Eco-Establishment, in Carol Purcell, ed, From Conservation to Ecology 123 (Crowell, 1973). In 1964, under the leadership of Joseph Fisher, RFF changed its focus from resource sufficiency to environmental quality. See Joseph $\mathrm{L}$. Fisher, New Directions, in Nash, ed, The American Environment 157-64 (cited in note 34).

49. See Hans H. Landsberg, Natural Resources for U.S. Growth: A Look Ahead to the Year 2000 (Johns Hopkins Press, 1964). Landsberg provided statistics and factual documentation for the argument that the United States should shift emphasis from resource quantity to environmental quality. In 1974 Landsberg found himself studying the "no-growth society." See Mancur Olson \& Hans H. Landsberg, eds, The No-Growth Society (W. W. Norton, 1973). See also Edwin T. Haefele, Representative Government and Environmental Management (Johns Hopkins Press, 1973). See Freeman, Haveman \& Kneese, The Economics of Environmental Policy (cited in note 6) (providing an excellent nontechnical introduction to environmental policy). For a more technical analysis, see Allen V. Kneese \& Blair T. Bower, Managing Water Quality: Economics, Technology, Institutions (Johns Hopkins Press, 1968).

50. For a provocative, popular work on the relationship between ecology and environmental problems, see Barry Cornmoner, The Closing Circle 29 (Alfred A. Knopf, 1971). According to Commoner, "the first law of ecology" is that "everything is connected to everything else." Id at 33. See also Edward J. Kormondy, Concepts of Ecology (Prentice Hall, 2d ed 1976).

51. See Douglas Costle, The Environmental Protection Agency, Its Origin and Role (unpublished paper) (copy on file with author). After serving as head of the Connecticut Environmental Protection Agency, Costle joined the staff of the Congressional Budget Office. In 1977, President Carter 
The Environmental Protection Group did not favor combining pollution control and natural resource programs. Three ideas-representing a mixture of expert advice and the principles and values of staff group membersdominated its deliberations. These ideas, discussed in turn below, provided a rationale for the group's recommendation to consolidate existing pollution control programs in a separate department.

First, the Group believed that new pollution problems were likely to develop that would strain the capacity of the fragmented environmental protection programs then in existence. An upgraded bureaucratic entity directly linked to the president was needed to anticipate pollution problems not yet discovered. Although scientists knew pollution was a serious problem, they did not completely grasp its magnitude. Increases in population, industrial production, mobility, and urbanization were expected to add to already serious pollution. Both the ability to monitor environmental hazards and the ability to detect the risks for the ecosystem were in the infancy of their development. The full risk of toxic chemicals, for example, only recently had been detected. ${ }^{52}$ Like radiation and pesticides, these poisonous substances crossed the traditional bureaucratic lines between air, water, and land pollution. Authority for toxic substances did not belong in NAPCA (HEW), FWPCA (Department of the Interior), or the pesticides program (Department of Agriculture). Nor did toxic substance regulation fit with other pollution programs. As a result, unless a new department or agency with an explicit pollution control mission were created, the federal government would not possess the organizational apparatus needed to detect new threats, such as toxic substances, or to take on new responsibilities for responding to such threats.

Second, the Environmental Protection Group believed that pollution control regulation and the promotion of economic development should be separated to avoid conflicts of interest. ${ }^{53}$ Many of the existing departments and agencies encouraged the growth of sectors of the economy that contributed to pollution, such as mining, petroleum extraction, nuclear power, and highway construction. Under the Group's view, the departments and agencies that stimulated this expansion should not administer a pollution

appointed Costle head of the Environmental Protection Agency. In 1975 Talley became EPA Assistant Administrator for Research and Development. Davies has served as an RFF scholar and executive vice president of the Conservation Foundation. He is now an EPA assistant administrator.

52. The CEQ first proposed in 1971 that Congress adopt a toxic substances control act, but no such legislation was adopted until 1976. The Toxic Substances Control Act enables the government to control the industries that produce the synthetic organic compounds used to make fibers, plastics, detergents, pesticides, and other products. It also permits regulation of such substances as asbestos and mercury as well as vinyl chloride, polychlorinated biphenyls ("PCB's"), and polybrominated biphenyls ("PBB's"). Toxic Substances Control Act, Pub L No 94-469, 90 Stat 2003 (1976), codified at 15 USC § 2601; see also Office of Toxic Substances, EPA, A Framework for the Control of Toxic Substances (April 1975) (a compilation of speeches).

53. A distinction can be drawn between the regulatory function and the promotion function of government. Merle Fainsod, Lincoln Gordon \& Joseph C. Palamountain, Jr., Government and the American Economy 81-109, 221-36 (W. W. Norton, revised ed 1948). See also James Q. Wilson, The Rise of the Bureaucratic State, The Public Interest 77-103 (1975). 
control program; rather, bureaucracies encouraging "exploitation" of the environment should be separated from those that were responsible for environmental protection. More specifically, conflict that existed in the past between resource development and pollution control should now be resolved in favor of environmental protection. If pollution control programs, for example, were combined with natural resource programs in a revitalized Department of the Interior, then the environmentalists would be overwhelmed by the better organized developers. The fox, as the staff put it, had to be kept out of the chicken coop; otherwise, the few who suffered the concentrated costs of environmental regulation were likely to prevail over the many who stood to gain the diffuse benefits of regulation. The promoters of economic development, represented by several departments, bureaus, and agencies in the federal structure, already outnumbered antipollution forces, which had no official representative. Fairness dictated that those favoring environmental protection also should have a structure within the federal bureaucracy supporting their concerns. ${ }^{54}$

Third, the Group believed that an integrated and systematic method had to be applied to the problem of managing the unwanted by-products of an affluent society. The concept of residuals management would have the government control as efficiently as possible the total quantity of wastes produced, regardless of the source, media, or form. Accordingly, it was necessary to reduce the amount of wastes generated, to recycle and reuse as much waste as possible, and to find a satisfactory method to dispose of wastes leftover. It was also necessary to study the interactions among different pollutants and different forms of pollution in order to base regulation standards on the total amount of pollution to which humans and the environment were exposed. An intellectual approach that recognized the inter-changeability of the different forms of pollution-air, water, and landwould prevent polluters from evading the law by converting wastes from one form of pollution to another. Such an approach would simplify matters for industries generating more than one kind of pollution, and it would encourage the consolidation of state, local, and regional pollution control agencies. Combining the different antipollution programs would also provide the benefit of comprehensive planning. If planning took place, new pollution problems would be less likely to develop in the process of controlling old ones.

54. Harold Seidman, who served as a consultant for the Ash Council, is an advocate of a "competitive approach" to bureaucratic reform. Under this approach, competing interests should be included within the administrative structure of the federal government so that no powerful segment of society is either excluded from participation or from gaining an equitable share of the benefits. See Harold Seidman, Politics, Position and Power 3-37, 271-87 (Oxford U Press, 1970).

An advocate of a similar competitive approach is Robert Levine of RAND who writes that "bureaucratic operations can be made more effective through competition, and competition can be promoted within a bureaucracy by the frequent creation of the new to challenge the old." Robert A. Levine, Public Planning: Failure and Redirection 160 (Basic Books, 1972). 
The Environmental Protection Group disagreed with Bradford's proposal to create a Department of the Environment and Natural Resources. It considered the task of implementing a national growth policy to be beyond the means of the proposed department. Decisions about growth involved more factors than the simple trade-off between resource development and environmental protection. Moreover, if pollution control and natural resource functions were consolidated in one department, other government programs that had an impact on the rate of growth would still remain outside such a department's control.

Another reason why the Environmental Protection Group objected to the proposal for a large, amalgamated department was their concern, as described in Part IV, that the better organized and financed natural resource interests would tend to prevail over the less well-organized and poorer environmentalists. Combining the promotion of resource development with pollution control regulation would build a permanent conflict of interest into the department, which the Secretary would have to resolve. Should strict antipollution standards be established, for instance, even if they would prevent the growth of mining, the spread of nuclear power, and the greater use of coal for electric power? The Environmental Protection Group felt that such conflicts of interests would not afflict the head of an environmental protection administration, who would be a single-minded advocate of pollution control.

The Environmental Protection Group doubted that incorporating so many diverse bureaucratic units in one department was politically feasible. For instance, it was believed unlikely that the Forest Service could be broken away from the Department of Agriculture; that the Atomic Energy Commission ("AEC") would be willing to give up its independent status; and that the Army Corps of Engineers could be unhinged from the Department of Defense. Neither the congressional committees that had oversight and appropriations responsibility for such bureaucracies nor the constituencies that the existing programs served would permit such broad departmental reform. The more limited task of combining pollution control activities in one administration was in itself difficult to achieve. It would prove even more difficult to undertake the transfer of the well-entrenched natural resource bureaus and commissions to a new department.

The Environmental Protection Group also argued against a Department of the Environment and Natural Resources on the ground that it would be a holding company too large and diverse to be effectively managed. Even after uniting the numerous resource and environmental programs into a single department, the programs would likely remain isolated. The programs' administrators would pursue separate goals without effective control or coordination over program activities by the Secretary. In contrast, a separate environmental protection administration might be able to merge and not just consolidate pollution control programs. It could break down old bureaucratic distinctions by organizing on the basis of function-research, standard 
setting, monitoring, enforcement, and state assistance-rather than on the basis of media-air, water, and land.

Amory Bradford ultimately accepted the Environmental Protection Group's arguments against a large amalgamated department. In his recommendation to Ash in March, he maintained that the merger of pollution control programs deserved first priority. The second priority was establishing a Department of Natural Resources that would unite renewable resource and energy and mineral programs.

In April, however, Ash rejected Bradford's recommendations. Ash's first choice was to bring together related natural resource and environmental functions in a Department of Natural Resources and the Environment. Ash chose this alternative because his grand design for the entire federal structure was to consolidate departments and reduce the number of officials reporting directly to the President. The premise of Ash's theory of reorganization was that competing interests should be united. Ash wanted to reduce the size of the cabinet and establish four super-departments-for community development, economic affairs, human resources, and natural resources-to rearrange and combine the various programs in HUD, HEW, Transportation, Interior, Agriculture, Labor, and Commerce. ${ }^{55}$ Because officials in these new departments would need to balance opposing interests, they would less likely be advocates of narrow points of view. Strong, loyal cabinet and sub-cabinet officials-carefully selected by the President-would manage the day-to-day operations of domestic programs. In turn, the Executive Office of the President would no longer be burdened with balancing competing interests. With fewer officials reporting directly to the White House, the President would be both significantly relieved of daily operating responsibilities and in greater control over the bureaucracy.

In this round, at least, Ash had the final say. Despite the objections of the Environmental Protection Group and their persuasion of Bradford, Ash's view prevailed. The proposed Department of Natural Resources and the Environment would consolidate such elements as the various pollution control programs, the AEC, the Forest Service, the Army Corps of Engineers, and the Department of the Interior. So consolidated, the new department would have been the fifth largest in the federal government.

\section{Departmental Opposition}

One day after Ash made his recommendation, the Ash Council met with the secretaries of various departments and the heads of CEQ and AEC to hear their comments. HEW Secretary Finch was opposed to any reorganization of the nation's environmental and natural resource programs. Secretaries Stans from Commerce, Hardin from Agriculture, Romney from HUD, and AEC administrator Seaborg also opposed the plan. They were against

55. Richard P. Nathan, The Administrative Presidency, The Public Interest 42-45 (Summer 1976). See also Richard P. Nathan, The Plot That Failed: Nixon and the Administration Presidency 59-62 (John Wiley \& Sons, 1975). 
reorganization because they stood to lose appropriations, personnel, and statutory responsibility. The chairman of CEQ, Russell Train, opposed establishing a super-department, but he favored creating separate pollution control and natural resource bureaucracies. Only Secretary Hickel of the Department of the Interior, which would be transformed the most, and Secretary Volpe of the Department of Transportation, which would be changed the least, supported Ash's recommendation.

HEW maintained that the proponents of reorganization should demonstrate that the long-term benefits of reorganization would outweigh its immediate costs. Transferring programs would disrupt their operations. Bureaucratic infighting and administrative concerns would consume time otherwise devoted to program administration during the period of transition.

Secretary of Commerce Maurice Stans discussed the problems of integration that he thought were associated with Ash's proposal. Mining, coal, and gas interests would try to prevent the consolidation of energy programs. Coordination of the different pollution control programs would be difficult since these programs had separate statutes, goals, and professional constituencies. On the one hand, the laws defined air pollution as a health problem, and air pollution regulation depended upon the research on health effects of medical scientists in the Public Health Service. On the other hand, the laws defined water pollution as a recreation problem, and sanitation engineers applied their expertise to the construction of sewage waste treatment plants that made waterways more fishable and swimmable. Different programs-granted authority by separate statutes, surrounded by diverse interests, and using different professional groups for implementation-would not be effectively consolidated or coordinated if housed in a single department. ${ }^{56}$

Stans also doubted the feasibility of the overall goal underlying Ash's reorganization plan for the federal bureaucracy: greater control by the President. Presidentially appointed cabinet and sub-cabinet officials of a super-department of natural resources would be in no position to control dayto-day operations of environmental regulation. To the extent that control over the bureaucracy was necessary, the President could best achieve it through the Office of Management and Budget ("OMB") and the Domestic Council in the Executive Office. ${ }^{57}$

The secretaries of Agriculture and HUD and the chairmen of AEC and CEQ had equally strong reservations about the feasibility and appropriateness of Ash's proposal. Agriculture Secretary Hardin mentioned that the wellorganized farm and chemical industries would oppose a switch in responsibility for pesticide regulation. HUD Secretary Romney noted that city governments and their urban poor constituents, many of whom were black, would not be pleased since they would interpret the creation of a

56. Marcus, Promise and Performance at 40-41 (cited in note 28).

57. Id. 
natural resources conglomerate as an indication that the federal government was abandoning their problems. AEC Chairman Seaborg claimed that his commission should not lose the right to set emissions standards because it needed this regulatory authority to carry out its nuclear power plant licensing function. Finally, CEQ Chairman Russell Train repeated some of the Environmental Protection Group's criticisms, for example, that uniting regulators with polluters in the same department would create conflicts of interest.

Secretary Hickel-one of the two supporters of Ash's proposalemphasized the need for a balanced growth policy. His support for the proposal, however, probably did more to discredit it in the eyes of Roy Ash and the White House than to further its progress. Among Nixon's supporters, Hickel was looked upon with disfavor because he had enthusiastically endorsed Earth Day and publicly criticized the President's environmental record.

The consequence of so much departmental opposition was a stalemate. Ash's proposal to create a super-department did not have enough support from the cabinet members whose departments it affected. The turning point came when HEW modified its stance. In a discussion paper sent to the Ash Council, HEW indicated a willingness to support the creation of an independent pollution control administration. Ideally, the paper argued, all environmental programs should be housed in HEW because they were public health programs. Doctors acknowledged that certain diseases were linked to environmental causes and that more research on health effects was needed. ${ }^{58}$ The drawback to placing all pollution control programs in HEW, however, was the enormous size of the department. Lacking visibility in such a large department, environmental programs would suffer when competing for funds against other programs.

The Environmental Protection Group, Bradford, CEQ, and now HEW favored separating pollution control from natural resource activities. All of these parties were thinking along the same lines, while those who were inclined to support a larger conglomerate had different reasons for doing so. The Domestic Council task force, Bradford (before he changed his opinion), and now Hickel saw the united department as a tool to implement a balanced national growth policy; Ash's purpose was to streamline the bureaucracy for more effective presidential management. Ultimately Ash withdrew his opposition to the staff proposal for a pollution control department that he previously had rejected.

In a memorandum to the President in late April, the Ash Council advocated merging key antipollution programs into a separate department or agency. In May, a second memorandum was sent to the White House that proposed establishing a Department of Natural Resources that would combine renewable and non-renewable resource programs. However, the

58. See René Dobus, Man Adapting 163-253 (Yale U Press, 1980). 
memorandum openly doubted the political feasibility of this plan because of opposition from AEC, the Corps of Engineers, the Department of Agriculture, and others.

The Environmental Protection Group insisted on a separate pollution control department and, despite the counterproposal of the Domestic Council task force, the initial opposition of Amory Bradford, the opposing theory of Roy Ash, and the resistance of departments and agencies, its view reached the President. One reason that the plan for a separate pollution control administration moved successfully through such a political obstacle course was that it stood between extremes. On the one hand, the Domestic Council task force, Bradford, and Ash favored consolidating all natural resource and pollution control programs. On the other hand, the Departments of HEW, Commerce, Agriculture, HUD, and the AEC-fearing that they would lose authority, resources, or personnel-saw no reason for such a large-scale transformation. While originally only a few influential senators favored an independent pollution control agency, in the end, Bradford, CEQ, and HEW, saw it as a compromise proposal and, as such, consented to support it.

\section{E. The President: Idealism Tempered}

In the final reorganization plans submitted to Congress in July 1970 , President Nixon made certain adjustments to the Ash Council recommendations. He appeased the dissenting cabinet members by maintaining programs they considered necessary to their departmental missions. The existing departments and AEC did not suffer as large a loss of personnel, resources, and authority as would have occurred under the Ash Council recommendations. Moreover, the President supported the notion that OMB and the Domestic Council, not CEQ, would resolve disputes between EPA and the other departments and agencies. The final credit for submitting the plan to create EPA to Congress belongs to President Nixon.

Although there was some quibbling from Congress, the proposal to create a new pollution control department was never in serious danger of rejection. Nixon cited the need to merge pollution control functions as the reason for creating the new agency:

Despite its complexity, for pollution control purposes the environment must be perceived as a single interrelated system. . . A single source may pollute the air with smoke and chemicals, the land with solid wastes, and a river or lake with chemical and other wastes. Control of the air pollution may produce more solid wastes which then pollute the land or water. Control of the water polluting effluent may convert it into solid wastes, which must be disposed of on land ... . A far more effective approach to pollution would:

- Identify pollutants;

- Trace them through the entire ecological chain, observing and recording changes in form as they occur;

- Determine the total exposure of man and his environment;

- Examine interactions among forms of pollution; and 
- Identify where on the ecological chain interdiction would be more appropriate. ${ }^{59}$

\section{The Functional Plan}

EPA's first administrator, William Ruckelshaus, had a number of priorities when he took over the agency. ${ }^{60}$ He wanted to create a well-defined enforcement image, to carry out scrupulously the provisions of the 1970 Clean Air Act, and to gain control over the regulatory decisionmaking process. He was also concerned with organizational matters and tried to structure the agency according to the Ash Council's plan for comprehensive environmental management. He attempted to implement the plan by systematically integrating the bureaucratic components he received from various agencies and departments. However, his efforts met with more resistance than his other initiatives in the areas of image-building, implementation, and control, and in the end were not very successful.

\section{A. The Administrator's Priorities}

Administrator Ruckelshaus's priorities were a product of demands he faced during EPA's first six months. Ruckelshaus had to demonstrate to environmentalists that EPA-unlike former pollution control bureaus-would be willing to take polluters to court. The Clean Air Act compelled him to issue national air quality goals. The White House pressured him to improve the agency's capabilities for analyzing the costs and benefits of its actions. Establishing priorities for the new agency was not a planned or orderly procedure. It was subject to constraints that limited Ruckelshaus's ability to act independently and to implement a structural plan for comprehensive management. Ruckelshaus compared the experience to "running a 100-yard dash, while undergoing an appendectomy." 61

Ruckelshaus could not command events or master the situation he faced. Rather, he coped with issues as they arose and responded to what he considered to be the demands of the moment. He struggled to find solutions that would accommodate conflicting interests and spent endless time and energy trying to persuade others to support the agency's activities. Moreover, despite some commitment to CEM, Ruckelshaus never fully embraced the Ash Council's top priority-organizing EPA according to the functional plan for CEM. Ruckelshaus could not decide whether to organize the agency strictly according to functional categories such as research, planning and management, standards, and compliance, or according to environmental

59. CEQ The First Annual Report at 294-305 (cited in note 20).

60. For readings on executive behavior, see Chester I. Barnard, The Functions of the Executive (Harvard U Press, 1968); Phillip Selznick, Leadership in Administration: A Sociological Interpretation (Harper \& Row, 1957); Marver Bernstein, The Job of the Federal Executive (Brookings Inst, 1956); Seidman, Politics, Position and Power (cited in note 54).

61. John Quarles, Cleaning Up America 32 (Houghton Mifflin, 1976). 
program areas focusing on different forms of pollution such as air, water, pesticides, and solid wastes. Instead of choosing one type of organizational framework, Ruckelshaus developed hybrid structures that incorporated elements of both the functional and the form-of-pollution organizational methods. Essentially he divided the agency's units in half-some assistant administrators had functional responsibilities and some had programmatic responsibilities.

There were a number of reasons why Ruckelshaus failed to organize the agency completely along functional lines. He considered structural features to be less important to the agency's effectiveness; consequently, other decisions regarding key personnel appointments, for example, or the banning of DDT and chemical detergents took precedence over structural issues. Moreover, in order to maintain the confidence of the inherited bureaucracy, he thought it best to avoid the disruption of its routines that would result from program integration. A disruption of standard operating procedures would have jeopardized EPA's success in meeting its statutory responsibilities by the prescribed deadlines. Disruption might also have led to dissension in the bureaucracy and to complaints to Muskie's subcommittee. These complaints would have blamed Nixon's appointees for the delays because they had insisted on program consolidation. Thus, because he wanted to assure bureaucratic confidence and because he had to deal with more pressing matters, Ruckelshaus failed to carry out the full functional plan.

\section{B. The Origins of the Functional Plan}

The origins of the functional plan date back to the period before EPA's creation, when Alain Enthoven, in the role of consultant, and Douglas Costle, in the role of task force coordinator, helped devise EPA's organizational strategy. Enthoven, a former Defense Department official, composed a functional plan that appeared in October 1970. It incorporated ideas that the Ash Council staff had been developing, which appealed to Enthoven because they applied the Defense Department's program planning experiments to EPA's organizational design. ${ }^{62}$ Just as Defense Department budget categories were broken down into functional units (such as strategic retaliation, general purpose, and air defense), EPA's organizational division also could be broken down according to functional units (such as abatement, monitoring, research, and standard setting). Like the Defense Department, EPA could adopt mission-based categories to break down artificial bureaucratic distinctions, eliminate duplication and waste, and achieve greater integration of operations. Enthoven argued forcefully for eliminating EPA's programmatic inheritance: its distinct air pollution control, water quality, solid waste, radiation, and pesticide components. EPA, according to Enthoven, should carry out President Nixon's expressed intent by dealing with the environment

62. See Alain C. Enthoven \& K. Wayne Smith, How Much is Enough: Shaping the Defense Program 1961-1969, $31-73$ (Harper \& Row, 1971). 
as an interrelated system. Abatement programs should not be evaluated on the basis of their effects on a single medium such as the air, water, or land.

Douglas Costle, head of the Ash Council's environmental protection group, directed a White House EPA task force that handled transitional issues. While still engaged in Ash Council deliberations, Costle had favored complete functionalization. He helped develop the concept of comprehensive waste management that Nixon used in his "Message Relative to the Reorganization," and he promoted the idea that pollution problems were interrelated. One of Costle's first undertakings as coordinator of the EPA task force was to prepare an "inventory" of EPA's inherited bureaucracies and programs. The results of this inventory reinforced his conviction that EPA's diverse holdings had to be integrated.

The inventory writers listed the bureaucratic pieces that EPA would be receiving, their budgets, work forces, cohesiveness, and statutory authority. ${ }^{63}$ A summary of their findings is helpful in understanding why Costle stressed functionalization. EPA's largest bureaucratic piece, the Fresh Water Quality Administration ("FWQA"), had been separated from the Bureau of Water Hygiene ("BWH") when it was moved out of the Department of Health, Education and Welfare by President Johnson in 1967.64 FWQA had a large budget but was obligated to spend 90 percent of it on sewage waste construction grants. BWH's water program monitored drinking water quality, but it had no enforcement powers. Air pollution control, EPA's second largest program, had a "research-first" image. ${ }^{65}$

The inventory writers, however, reserved most of their criticism for the pesticides, radiation, and solid waste programs. With respect to the pesticides program, they were concerned that a diversity of purposes could impede progress. The Pesticides Registration Division from the Department of Agriculture tested the efficacy of insect killers; the division inherited from the Department of Interior examined the effects of these substances on fish and wildlife; and the Pesticides Research Office from the Food and Drug Administration researched human tolerance to pesticides. A lack of enforcement authority could also impede progress because the right to remove food contaminated with pesticides from the market remained with the FDA. A similar lack of enforcement authority was likely to impede radiation control progress. EPA could establish emission limits, but enforcement power rested with the Atomic Energy Commission, which licensed atomic power plants. The inventory writers further noted that EPA inherited a relatively small solid waste program. ${ }^{66}$ In comparison to the other programs, the solid waste program had few employees, a small budget, and little

63. Message of the President Relative to Reorganization Plans Nos 3 \& 4 of 1970, July 9, 1970, in CEQ, The First Annual Report at 295-98 (cited in note 20).

64. See Water Quality and the Interior Department: An Aborted Experiment (Natl Acad Pub Admin, 1971).

65. Esposito, Vanishing Air at 182 (cited in note 17).

66. Marcus, What Does Reorganization Accomplish at 121 (cited in note 29). 
statutory authority. Even though the 1970 Resources Recovery Act ${ }^{67}$ authorized spending $\$ 460$ million over three years on waste recycling research, the solid waste program was EPA's least significant inheritance. A lack of cohesion, enforcement authority, money, and personnel limited the capability of the program.

These factors convinced Costle that EPA's bureaucratic pieces should be molded into an agency with a comprehensive pollution control identity. EPA could not afford to become a big holding company like HEW or the Department of the Interior. The secretaries of those departments had little power over independent units that had independent constituencies and congressional relations. EPA needed strong management from the top. Costle felt that its organizational structure should conform to the pattern found in the Department of Defense, NASA, and AEC.

However, in deciding how to devise an organizational strategy for EPA, Costle balanced the need for integration with the need to get a rapid start in dealing with the problems EPA expected to handle. He feared that by crosscutting the categorical programs, pulling them apart, and assigning personnel by function, the new administrator would create chaos. Work would come to a halt, and the ensuing confusion would paralyze the agency's efforts. If the full functional scheme were put into effect, the agency would not be able to carry out more pressing responsibilities, such as banning chemicals, preparing a budget, developing legislative proposals, and bringing violators to court.

\section{The Three-Stage Strategy}

Costle concluded that although a functional organization was the appropriate long-term goal for the agency, only incremental change was reasonable and feasible in the short run. The message conveyed to Ruckelshaus at the initial briefing on organization and management options was that, at first, EPA should maintain the continuity of program identity necessary to achieve immediate objectives. The administrator should lay only the groundwork for implementing the full functional scheme at this time. In a follow-up period, Ruckelshaus would be able to overcome the limitations of the holding company model and ensure comprehensive environmental management.

Costle recommended a three-stage strategy for organizational change. ${ }^{68}$ The initial structure of the agency would preserve the five program areas as illustrated in Figure 1.69 The two assistant administrators would be part of the administrator's staff and would have no responsibility for operations. After a period of time, the agency would move closer to the functional ideal.

67. Resource Recovery Act of 1970, Pub L No 91-512, 84 Stat 1227 (October 26, 1970). See Mills, Design for Environmental Protection at 18 (cited in note 27); Rosenbaum, The Politics of Environmental Concern at 247-49 (cited in note 12).

68. See William R. Ahern, Jr., Organizing for Pollution Control: The Beginning of the Environmental Protection Agency. 1970-71, 29-34 (JFK School of Govt, 1973).

69. Marcus, What Does Reorganization Accomplish at 123 (cited in note 29). 
Costle imagined that the agency's second organizational chart would look like Figure 2.70 This structure would put greater distance between the administrator and the three assistant administrators' offices that would begin to take over the functional administration of the programs. Finally, after more time had elapsed, the agency would work toward complete functionalization. Costle imagined that the final organizational chart would look like Figure $3 .{ }^{71}$ The final organization would give priority to five functions: (1) planning and management; (2) standards and compliance; (3) regional programs; (4) national programs; and (5) research and monitoring. It would encourage a systems approach to environmental management and increase executive control by eliminating old organizational identities.

Figure 1

Initial Organizational Chart (Costle)

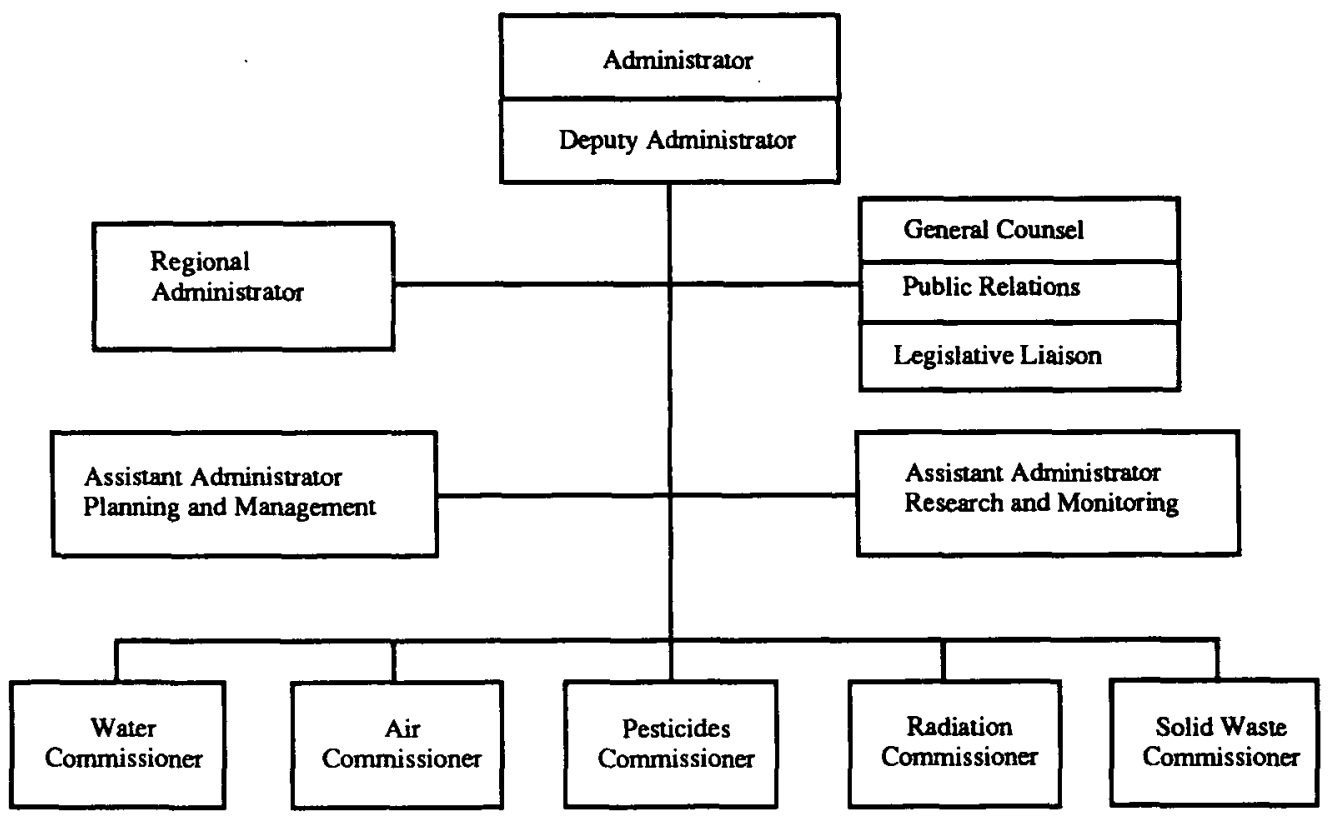

\section{Ruckelshaus's Response}

Ruckelshaus, while making slight modifications, essentially carried out the first two parts of Costle's three-stage plan. At the start of his tenure, he set up a system in which commissioners administered discrete EPA programs. For the time being, his purpose was to continue with important existing activities, while creating a more effective organization later. ${ }^{72}$ The commissioner

70. Id.

71. Id at 124 .

72. Ahern, Organizing for Pollution Control (cited in note 68); see also Robert Gillette, Environmental Protection Agency: Chaos or Creative Tension?, 173 Science 703-07 (Aug 20, 1971); Richard Corrigan, Agency Report/EPA Ending lear-Long Shakedown Cruise, Natl J Rep 2039-47 (Oct 9, 1971). 
Figure 2

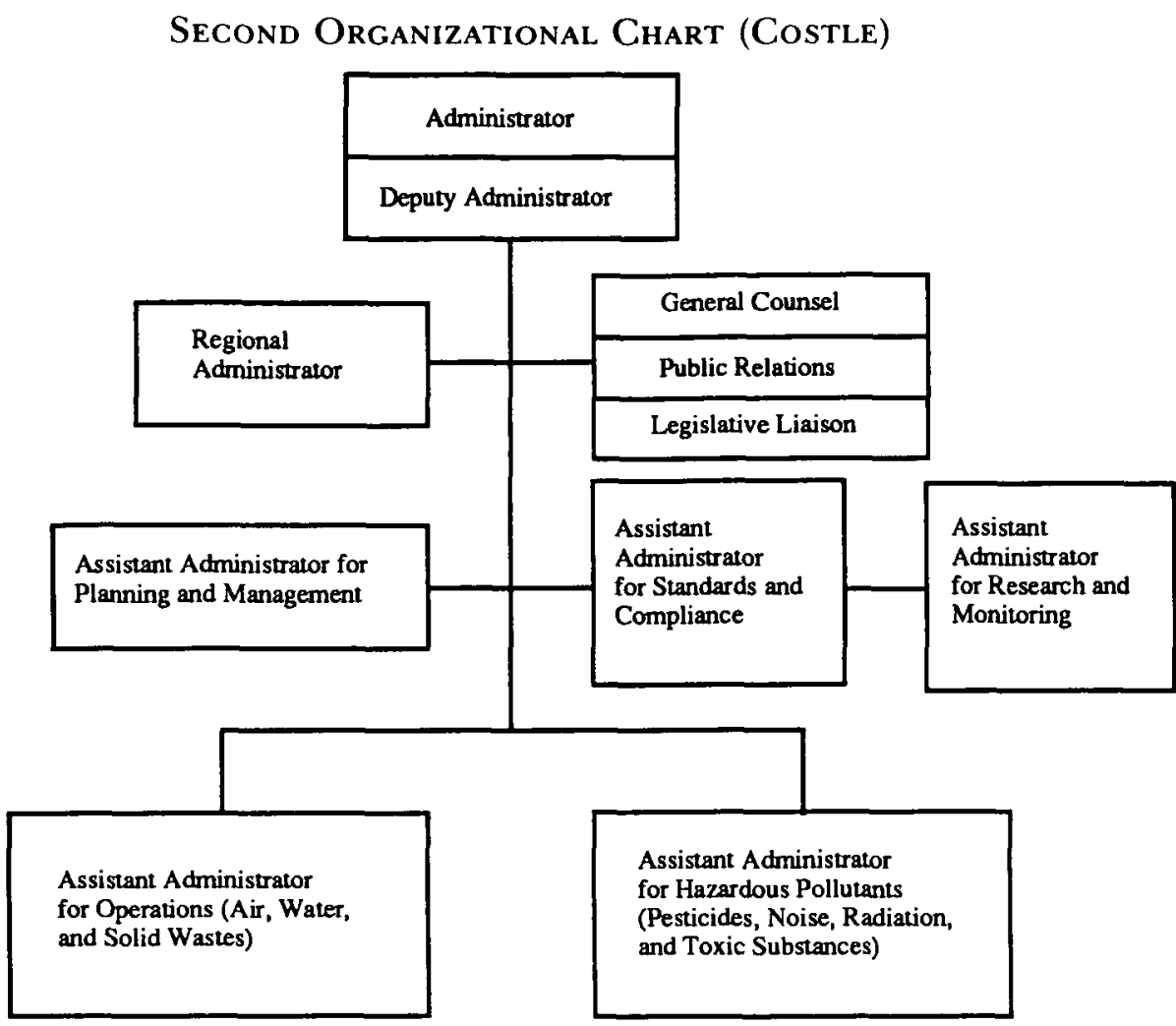

Figure 3

Final. Organizational Chart (Costle)

Assistant

Administrator

for Planning and

Management

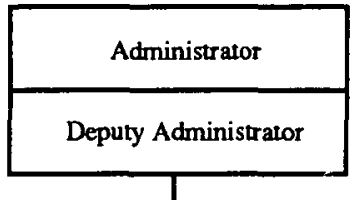

Administrator

for Standards

and Compliance

\begin{tabular}{|l|}
\hline General Counsel \\
\hline Public Relations \\
\hline Legislative Liaison \\
\hline
\end{tabular}

Assistant

Administrator

for Regional

Programs
Assistant

Administrator

for Research

and Monitoring 
system, Ruckelshaus said, would be temporary. In time, the agency would move toward a different structure.

Figure $4^{73}$ illustrates the agency structure under the commissioner system that Ruckelshaus approved in December 1970. In addition to the five commissioners, the original plan provided for three assistant administrators for Planning and Management, Standards and Enforcement and General Counsel, and Research and Monitoring. These assistant administrators would operate more as staff to the administrator than as managers with large operating bureaucracies under their direction. Two other assistant administrators had been assigned to the agency, but their duties were still uncertain. Ruckelshaus added an assistant administrator for field coordination to Costle's initial scheme as a temporary position in order to

Figure 4

Commissioner System Structure (Ruckelshaus)

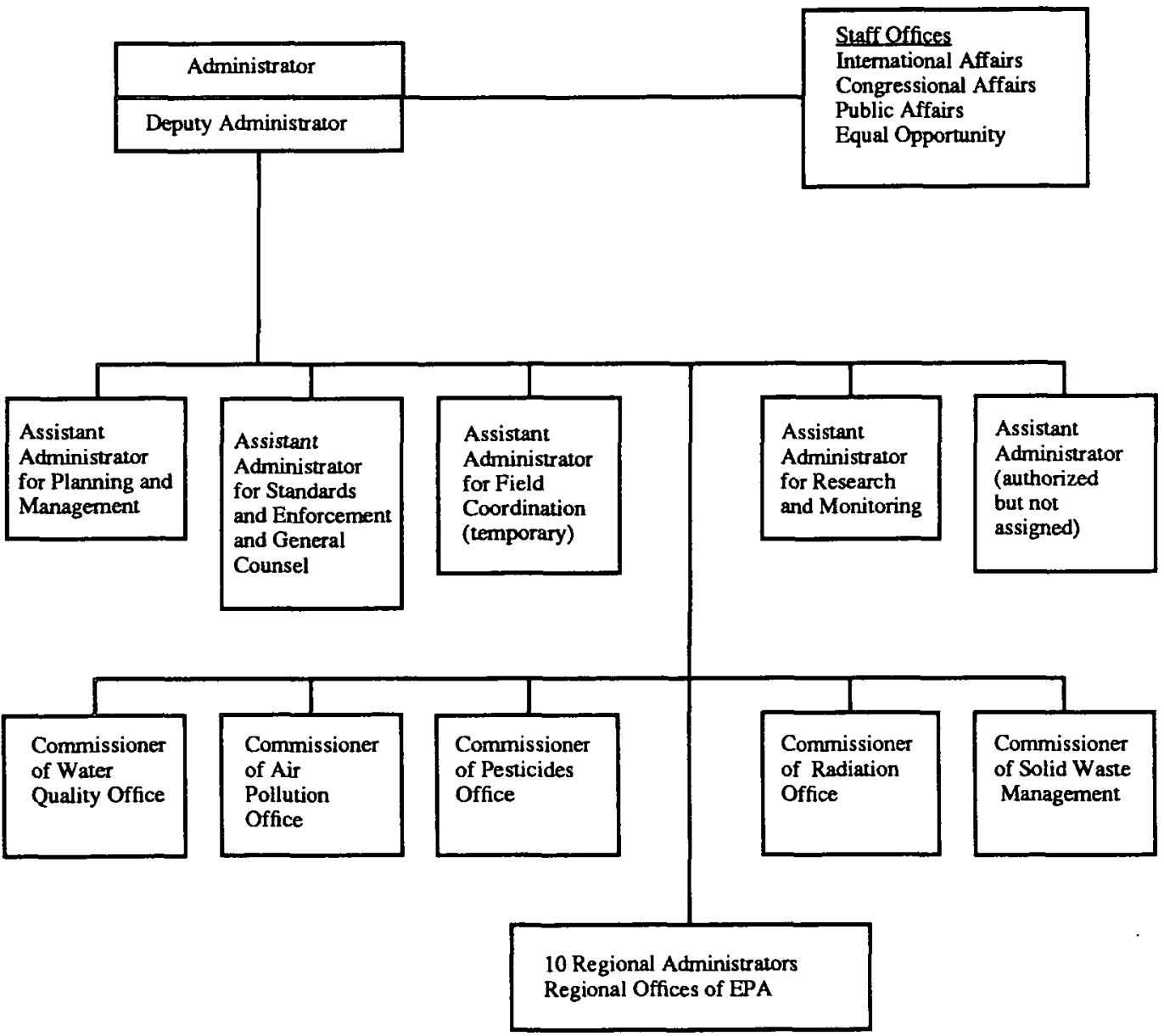

73. Marcus, What Does Reorganization Accomplish at 125 (cited in note 29). 
Figure 5

Second Organizational Plan (Ruckelshaus)

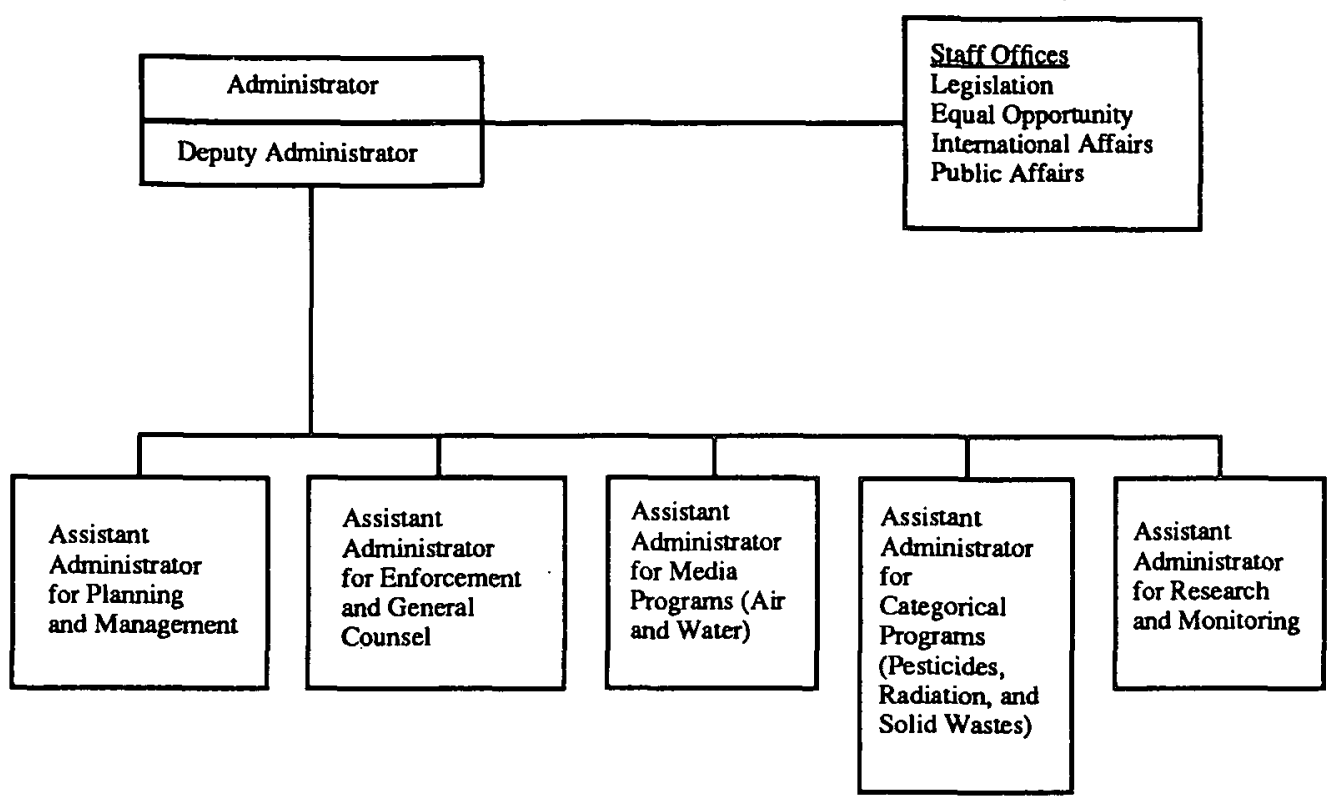

obtain a better understanding of the agency's regional operations. Unlike Costle, Ruckelshaus combined the general counsel's duties with the standards and enforcement function and gave this position assistant administrator status as a way to emphasize EPA's intention to bring pollution control violators to court.

Five months later Ruckelshaus drew up a second organizational plan illustrated by Figure 5. ${ }^{74}$ This structure basically corresponded to the second stage envisioned by Costle, except for the media office, which combined the air and water programs. The media office was meant to establish methods of communication where none previously existed. Ruckelshaus hoped that the interaction among previously separate elements would generate new ideas.

Although Ruckelshaus carried out the first two stages of the plan, he failed to push the agency to stage three and a complete functional scheme; the program offices survived and maintained their distinct identities. Why was functionalization not completed? In part, Ruckelshaus shied away from functionalization because he felt that structure was not as important as personnel. Having worked all his life with lawyers in a collegial environment, he had no experience managing a hierarchical agency. He did not feel that he understood the jargon used by his organizational advisors and the meaning of the charts they brought to him. He believed that the success of an

74. Id at 126 . 
organizational scheme depended upon getting key people to make it work, and that there was no magic in any particular structure. ${ }^{75}$

Another reason that Ruckelshaus did not completely functionalize the agency was his fear of mutiny on the part of the inherited bureaucracy. Inherited personnel might not have adjusted to complete functionalization; morale would have suffered, and the agency would have been paralyzed. Alienated bureaucrats might have complained to Congress, where they were likely to find a receptive audience. Senators and representatives themselves would have been confused by an organization that eliminated programmatic distinctions tied to existing committees. Ruckelshaus believed that the inherited programs had to maintain continuity to avoid the prospect of congressional criticism; as a result, he did not fully implement the functional plan.

Thus the concept of comprehensive management that began with slogans such as "spaceship earth" and "eco-balance" was tempered by the politics of reorganization and further weakened when the functional plan was not fully adopted. The President's message promised that the new agency would eliminate artificial distinctions between media, ${ }^{76}$ but EPA's organizational scheme maintained these distinctions. The message advocated systematic management by which pollutants would be traced through the entire ecological chain, their interactions examined, and the total exposure of man and the environment determined; but an organization that conducted specific programs in the fields of air pollution, water quality, solid wastes, radiation, and pesticides could not carry out such systematic management.

\section{$\mathrm{V}$}

\section{The Limitations of Comprehensive Environmental MANAGEMENT}

The Ash Council's staff set noble goals for the new EPA: managing pollution in a way that reflected the interrelatedness of the environment, preventing unintended environmental side effects, and achieving a balanced rate of growth. However, for the first twenty years of EPA's existence, these goals remained unattainable as the narrow perspectives of bureaucrats worked against achieving such broad principles. Program managers were tied to specific laws, functions, and appropriations that perpetuated longstanding pollution control distinctions. Regional administrators had local connections and enough independence not to act in concert with Washington. Consequently, EPA remained in many respects a coalition of small fiefdomsseparate programs, regional offices, and administrative staffs. On a more basic level, EPA lacked rudimentary information about how the environment functions and the concrete effects of pollution. This knowledge gap hindered $72)$.

75. Corrigan, Natl J Rep at 2043 (cited in note 72); Gillette, 173 Science at 705 (cited in note

76. See note 22 and accompanying text. 
the agency in its attempt to control environmental degradation and protect human health. Moreover, the administrator's staff dealt with immediate problems, lacking time to consider broad policy options and goals. The agency also was unable to develop a measure for total environmental progress; nor did it have the information to assess which problems deserved first claim on its resources.

\section{A. Structural Limits Within EPA}

Presidents, professional reformers, and social scientists could afford to discuss the environment in terms of comprehensive principles, because they were detached from the day-to-day responsibility for specific programs. EPA's bureaucrats, in contrast, could not deliberate about the largest possible range of environmental phenomena and concerns. Their position in EPA's structure and their delegated tasks limited their view of environmental problems. Policymakers assumed that the environment could be perceived from a broad uniform perspective, such as in the metaphors of spaceship earth or in the concepts of the material balance model, but they did not take into account that bureaucrats in EPA viewed specific environmental problems from a variety of narrow vantage points.

This section attempts to explain why the bureaucrats-divided by legal, regional, and professional differences-did not implement the systematic notions underlying CEM entertained by policymakers at the time of EPA's organization. It examines the principles of comprehensive management from the perspective of different parts of the bureaucracy-program managers, regional administrators and the states, the administrator's staff, and EPA's research apparatus-and shows why the reorganization did not succeed in achieving CEM.

1. Program Managers. Barriers to the implementation of CEM existed at the highest levels of the agency. Program managers, the highest ranking Washington-based civil servants, saw no compelling reason to eliminate the former categories of pollution control. EPA's programs came from large departments (HEW, Interior, and Agriculture) where program managers enjoyed substantial autonomy. EPA's managers were inclined to believe that the agency should have been a pure holding company with five separate subsidiaries addressing the distinct pollution problems of air, water, pesticides, radiation and noise, and solid wastes. Since these managers believed that pollution rarely crossed program lines, they expected that the agency could solve these exceptional cases as they arose.

Program managers also had personal interests in maintaining the status quo and keeping programs separate. Many of them had worked in their particular fields for twenty years or more and had carved out very specific areas of expertise. Managers resisted major change because they had invested time and effort in existing policy and procedure. They felt comfortable with 
the established decisionmaking process and operating procedures, which they felt incorporated the wisdom of experience.

Finally, program managers resisted the elimination of pollution control distinctions because they approached their jobs in terms of the separate statutory requirements they had to fulfill. They responded to a series of pollution control laws enacted by Congress, not to the President's declaration of comprehensiveness. While the President asked for structural reform, he did not propose that Congress pass an environmental bill that would require the new agency to pursue a comprehensive method.

Instead, EPA had to administer separate air, water, pesticide, noise, solid waste, and radiation acts. These statutes reflected the fragmented nature of the legislative branch where eight House committees, seven Senate committees, and one joint committee each had some jurisdiction over pollution control. The result was a perpetuation of old loyalties and communication patterns among EPA's programs.

Congress did not have the will to reorganize its fragmented committee structure or the foresight to change the piecemeal way in which it considered pollution problems. Legislation and committee jurisdiction continued to be based on the narrowly defined separation between programs. Congress deliberated on each law separately and amended them according to legal and political concepts that were not compatible with a comprehensive, but more functional plan. ${ }^{77}$

EPA did attempt to organize part of its bureaucracy according to comprehensive management principles, but Congress's fragmented approach to pollution control blocked its efforts. For example, two of EPA's largest and best-funded programs, which dealt with air and water quality, were for a time placed under a single assistant administrator in the media office. Yet, each program had a distinct conceptual basis and statutory and procedural mandate. ${ }^{78}$ For instance, the air pollution program focused primarily on the long-term hazard to human health, while the water pollution program's major concern was removing organic material from waterways. The two programs were eventually separated.

A comprehensive environmental protection act would have given EPA a single mission such as protection of human life and environment. Instead of separate enforcement agents for air and water pollution, a single enforcement officer would have been responsible for all the pollution a plant generated. If uniform provisions had applied to different media and forms of pollution,

77. For detailed information on EPA's legal authorities, see EPA, Legal Compilation: Statutes and Legislative History, Executive Orders, Regulations, and Guidelines and Reports (US Govt Printing Office, 1973). A good summary of EPA's statutes (pre-1972) is provided by The Challenge of the Environment: A Primer on EPA's Statutory Authority (EPA, 1972).

78. See Water Quality Strategy Paper (EPA, 1975); Air Program Policy Statement (EPA, 1974). According to the Clean Air Act, air quality goals were based on health and welfare criteria; according to the water pollution act, discharge limitations were based on technological and economic considerations. The national air pollution office established quality goals while the states set discharge limitations. The national water pollution office set discharge limitations, while the states established quality goals. 
administration would have been simpler and perhaps would have proceeded more smoothly. Unfortunately, Congress did not view the environment as a single interrelated system, and program managers had to fulfill statutory obligations that were not compatible with implementing CEM. ${ }^{79}$

2. The States and Regional Administrators. The states and regional administrators represented another institutional barrier to a functional plan. In order to implement a comprehensive national environmental policy, EPA needed the ability to manage the pollution control programs and the groups carrying out national environmental policy. However, the air and water pollution control legislation passed by Congress demanded extensive state participation. Consequently, the agency was dependent on the states for performance of crucial activities.

For example, the ambient air quality standards established in Washington were to be implemented at the state level. The federal government stepped in only if the states could not or would not implement them. Also, state water quality programs continued to operate, the states distributed water construction grants, and the 1972 water amendments gave the states the right to administer their own permit programs provided they fulfilled regional guidelines. ${ }^{80}$ The White House philosophy favoring decentralization provided further incentive to this sharing of power between the states and the federal government. ${ }^{81}$

To manage this delegation of power to the states, EPA set up regional offices. ${ }^{82}$ Unfortunately, this attempt to control state action created problems of its own. The regional administrators perceived issues not only in terms of their own obligations to headquarters, but also in terms of their commitments to the states. In fact, if a regional administrator became aligned with the states' interests he or she could block decisive agency action by refusing to carry out national policy. ${ }^{83}$ Headquarters could do little to coerce a regional administrator to change his or her ways, because, once appointed, a regional administrator quickly became entrenched. EPA in Washington could risk firing a regional administrator only if it was willing to alienate his or her local supporters.

Efforts by EPA to gain greater control over the regional offices met with limited success. Headquarters tried setting up the Management By Objectives

79. This failure on the part of Congress reflects, however, that in most instances, the American government is too divided to deal comprehensively with issues. Separate branches, a federal structure, and constitutionally mandated checks and balances impede efforts to develop integrative principles and to deal broadly with problems. Ordinarily, when conflicting interests have equal rights and separate units of government have different responsibilities, ends are not clearly articulated, means carefully chosen, or plans vigorously pursued.

80. Federal Water Pollution Control Act Amendments of 1972, Pub L No 92-500. 86 Stat 816 codified at 33 USC $\$ 1251$ (b) (1988)

81. See Report of the Decentralization Task Force (EPA, Dec 1975).

82. For a history and evaluation of EPA's regional offices, see Regional Organization (EPA Office of Planning and Management).

83. See Steven M. Lierberman, State and Regional Perspectives on the Environmental Protection "Service Delivery System" (Comm Envir Decision Making, 1976). 
("MBO") system by sending each region a manual that stated national objectives and listed priorities, ${ }^{84}$ and by allocating resources on the basis of a region attaining its goals of meeting specified outputs. ${ }^{85}$ The regions and states became committed to precise quantities of these outputs, which were the bases for their yearly work plans.

The MBO system, however, turned out to be ineffective for implementing CEM. The regions, in order to reach their commitments, tended to perform the easiest outputs first, not the outputs that would most benefit the overall environment. Consequently, it was impossible to judge whether the output numbers requested by headquarters actually contributed to overall environmental progress. A region might achieve all the expected numerical goals and still not improve or even maintain the quality of the total environment. Thus, while the $\mathrm{MBO}$ system gave headquarters some control over the regions, it did not give EPA enough control to assure the effective concerted action needed to implement comprehensive environmental principals.

3. The Administrator's Staff. The administrator's staff was unable to consider broad policy options and goals because it had to cope with changing political and economic circumstances. In 1970, the agency faced public pressure to regulate without regard for cost. The national consensus in favor of environmental action, however, quickly dissolved with the appearance of the economic downturn and the energy crisis of the early 1970s. In fact, relations with the White House eventually became strained because EPA was not paying enough attention to economic issues.

Therefore, the administrator's staff tried to make sure that every regulation underwent sound economic analysis and struck the proper balance between environmental and economic concerns. ${ }^{86}$ EPA also examined the effect of each regulation on both the targeted industry and its surrounding community. The administrator's staff had to focus on trade-offs between jobs, prices, energy, and the environment to protect the agency against damaging charges that its actions were contributing to unemployment, inflation, and energy dependence. As a result, the agency developed a short-term focus rather than the long-term perspective needed for considering broad options and goals.

Decisions on comprehensive environmental policy ran a good risk of upsetting major political groups, while in turn not making any other group happy. After the oil embargo of 1973, the Planning and Evaluation Office analyzed the use of scrubber technology for power plants. It suggested that in

84. See, for example, FY77 Regional Guidance (EPA, Feb 18, 1976).

85. For example, in 1974 the quantifiable outputs in water pollution included: (1) water waste treatment plants in compliance with standards; (2) enforcement actions taken; (3) state permit programs approved; (4) agricultural permits issued; (5) ocean dumping permits issued; and (6) construction grants awarded.

86. See, for example, Economic Analysis of Proposed Effluent Guidelines: Fruit and Vegetable Processing Indusiry (EPA, 1973). 
rural areas industry be permitted to use supplementary control systems without scrubbers-a suggestion that outraged environmentalists. At the same time, it suggested that industry install scrubbers on all new power plants in urban areas-a suggestion that outraged industry. Political pressures such as these often kept the administrator's staff from making any decisions on controversial issues and restrained the agency's attempts to pursue a comprehensive environmental policy.

4. Researchers. A major component in implementing CEM involved reorganizing environmental research along functional lines. Coordination among research projects was required to help the programs and regions deal with the environment in its entirety. However, EPA inherited a large, unwieldy research arm from the old environmental programs, consisting of fifteen diverse research laboratories in nine states. In 1972, the research office had a $\$ 165$ million budget and 2,000 employees from sixty different scientific and professional disciplines who were widely dispersed in the United States.

Researchers and laboratories resisted attempts by Washington to coordinate research operations. To a large extent, the laboratories retained their old identities rather than fitting into the new organizational scheme. For example, under a plan to consolidate laboratories into four National Environmental Research Centers ("NERC"), ${ }^{87}$ the North Carolina NERC was supposed to perform research only in the area of health and welfare effects. However, it continued to do work in all areas of air pollution, while a Cincinnati laboratory continued its research into health and welfare effects.

Agency scientists who had spent many years of their lives on specific projects were reluctant to abandon them suddenly because headquarters called for a reorganization. They argued that their current skills were not readily transferable to other fields of research. For instance, the water research program was strongly oriented toward developing technology for treating point source waste, while the air pollution research program was mostly concerned with health effects. Scientists in these programs argued that it was at best inefficient and at worst impossible for them to shift gears abruptly and devote their energies to new fields of research. Moreover, Congress itself blocked plans to consolidate and upgrade the laboratories. For example, it resisted the closing of outdated laboratories because they were community institutions that provided employment to local citizens. Furthermore, the laboratory managers themselves opposed reorganization

87. The first Assistant Administrator for Research and Monitoring, Stanley Greentield, attempted to consolidate data and coordinate research operations by creating four National Environmental Research Centers ("NERC"). He tried to match NERC themes with the previous capability and major expertise of the laboratories. The Corvallis, Oregon center, with reporting laboratories in seven locations throughout the United States, was supposed to be organized around the theme of ecological effects. The Cincinnati center, with laboratories in three locations, had as its theme pollution control technology. The Research Triangle Park, North Carolina facility stressed health effects and had laboratories in four states. Finally, Las Vegas, which had laboratories in five locations, emphasized monitoring. 
along functional lines because, if properly implemented, it would give Washington control over their operations. The research scientists in the laboratories considered themselves to be independent professionals doing pure science, as opposed to the scientists at headquarters who combined science with politics and management; 88 to them, Washington scientists did not understand how the laboratory should function. Therefore, laboratory managers maintained that headquarters should be separated from the day-today operations of the laboratories.

Finally, even if the laboratories had been reorganized, it is unlikely they could have contributed greatly toward achieving a comprehensive environmental management plan. According to EPA researchers, their first priority had to be upgrading the state of the art. They needed ongoing interaction with their professional counterparts in academia and in industry so their own work would be of comparable quality and reliability. And, since the environmental discipline was undeveloped, pure research was more important than practical research.

This approach was inconsistent with the needs of the programs and regions, which focused on technical support and service, and required knowledge and equipment that applied to unique problems. Researchers, however, maintained that since ecological sciences were underdeveloped, such definitive answers could not be produced immediately. Also, researchers felt that if they started a new project every six months because of immediate needs and did not develop an overall, long-term plan, the discipline of environmental sciences would never mature enough to cope with the difficult problems of the future.

As a result of their resistance to change, the scientists' role became technology development and transfer, not technology application. ${ }^{89}$ More broadly, the inability of the agency to functionalize the research arm contributed significantly to the failure of regions and programs to deal with the environment as a whole. ${ }^{90}$

88. See, for example, Walter Hirsch, Scientists in American Society (Random House, 1968); James L. Penick, Jr., et al, The Politics of American Science (Rand McNally, 1965).

89. This method was used with monitoring. Researchers solved the problem of standard analytical methods and designed the monitoring system using flow charts to figure out the part of the river, the portion of the air, and the industries on which the equipment should be installed. They provided the regional offices with quality control procedures for the surveillance required by statute, and the regions applied these procedures by doing the actual monitoring. On EPA's monitoring problems, see Task Force Report: EPA Strategy for Managing Monitoring: Issues and Alternatives (EPA, 1972); First Report of the Environmental Measures Project: Analysis and Applications of Environmental Quality Indicators (EPA, 1975); Surveillance and Analysis Division Study (EPA, 1975); Air Pollution Indices Used in the United States and Canada (CEQ \& EPA, 1975).

90. The regions required very specific information. For example, a regional administrator might want to know the ramifications from the runoff of alkaline Colorado soil into the area's rivers. One regional administrator's request for information would be combined with similar requests for information from other regions by the research office. Seeking to get as much knowledge for the fewest dollars possible, the research office combined thousands of agency requests into a much smaller group of projects. The different questions about soil alkalinity and runoff would be perceived as a complicated problem that required the completion of three or four tasks for a solution. Part of each task might be carried out in-house and part might be contracted out or done 


\section{B. Information Barriers}

There remains a final question of whether CEM could have been achieved at all. Even if authority had been organized along functional lines, the intellectual tools for comprehensively managing the environment may not have been available. The Council on Environmental Quality admits:

Our ignorance of the interrelationship of separate pollution problems is a handicap in devising control strategies .... Indeed, does it do any good to talk about pollution in general, or must we deal with a series of particular pollution problems-radiation, pesticides, solid waste? A systems approach is needed, but what kind of system? $[\mathrm{M}]$ uch more thought is necessary before we can be confident that we have the intellectual tools necessary to delineate accurately the problem and long-range strategies for action. 91

EPA's monitoring system required state agencies and regional programs to provide information suitable for enforcing particular statutes but was not appropriate for evaluating overall environmental quality. For example, the agency could determine how many states were violating air quality standards and how many industries were not complying with their permits. The agency had trouble, however, moving from these facts about violators to figures about overall air and water quality.

Another major problem was the length of time it took to gather and analyze data. The best data available at a given moment was almost always out of date. ${ }^{92}$ This created problems with definitions of air and water quality. National standards defined air quality in terms of the emissions of six pollutants into the atmosphere: total suspended particulates, sulphur dioxide, carbon monoxide, photochemical oxidants, nitrogen dioxide, and hydrocarbons. Scientists had discovered these pollutants many years earlier, and it was no longer certain if they still represented the most dangerous emissions. In 1975, the Council on Environmental Quality admitted: "It is becoming increasingly evident that the air pollutants upon which our standards and monitoring have been focusing do not represent all important parameters of air quality. In some cases, they may not even represent the most important or informative ones." 93 In 1975, water pollution standards used sixteen general variables, fifteen trace metals, and twelve pesticides for evaluation, but countless other factors could have been taken into account. For instance, PCBs only had been discovered to be dangerous in 1971, and the list of water pollutants was constantly growing. Without information about the total exposure to humans and the environment, the agency could not trace pollutants through the eco-chain, examine interactions among them, and identify where interdiction was most fitting.

by grant. The total report would be returned to the regional administrators in pieces of varying quality. The pieces would examine the problem in general and would have little to say about the region's specific problem. The regions were dissatisfied with this "needs" system, because they had numerous detailed needs that the system left unsatisfied.

91. CEQ, Environmental Quality: The Sixth Annual Report 326 (US Govt Printing Office, 1975).

92. See id at 336-37.

93. Id at $326,336-37$. 


\section{Conclusion: The Implications of EPA's Structure}

After this long story of EPA's origins and early development, I am now in a position to speculate about the impact EPA's structure had on the policies it adopted. First, I reiterate what I believe to be the distinctive features of EPA's structure. Then, I consider what types of policy implications may be derived from these structural features.

This article has identified three unique features of EPA's structure. First, EPA has been given a status in the federal bureaucracy as an environmental agency and not a natural resource and environment department as once contemplated by Roy Ash, one of its founders. Second, EPA has largely retained a programmatic format. Internally, it remains divided among its air, water, solid waste, pesticide, and other components, rather than having a thorough-going functional design as envisaged by Alain Enthoven, another prominent founder. ${ }^{94}$

A third distinct feature of EPA is that it is an independent regulatory agency without plural leadership. It is neither a component of another department like some agencies (for example, the Occupational Safety and Health Administration in the Department of Labor or the Food and Drug Administration in the Health and Human Services Department), nor is it outside a department and governed by a group of commissioners (like the Federal Trade Commission or the Nuclear Regulatory Commission). Rather, EPA has a single leader. ${ }^{95}$

EPA's structure has had some notably deleterious consequences for the agency. The focus on the environment to the exclusion of natural resources has limited EPA's response to supply interruptions, specifically the energy price hikes of 1973, 1979, and 1990. Conceptually, too, natural resource and environmental issues are intimately connected. Consider, for instance, their unity in both the scholarly and theoretical work done by the economically oriented think-tank Resources for the Future, ${ }^{96}$ the partisan work done by the conservationist and promoter of alternative life-styles, Amory Lovins, ${ }^{97}$ and the way they manifest themselves in an issue such as carbon dioxide buildup. ${ }^{98}$ Because EPA is separate from the Department of Energy and parts

94. Interestingly, both Ash and Enthoven have their roots in the business sector where the form an organization takes is not as influenced by interest group pressures and congressional enactments.

95. Since its inception in 1970, EPA has had only six administrators (William Ruckelshaus, who was the head of the agency twice, Russell Train, Douglas Costle, Anne Gorsuch, Lee Thomas, and at present William Reilly).

96. For an example of scholarly work by Resources for the Future that ties together energy and environmental issues, see V. K. Smith, ed, Scarcity and Growth Reconsidered (Johns Hopkins Press, 1979).

97. Lovins' most influential book remains Soft Energy' Paths: Toward a Durable Peace (Friends of the Earth, 1977)

98. The source of carbon dioxide buildup is the burning of fossil fuels. The need for fossil fuels generates society's energy problems, while the burning of these fuels yields serious environmental difficulties. A simultaneous attack on these two problems would permit an integrated resolution, rather than two solutions at odds with each other. 
of the Department of the Interior, it cannot fully exploit the insights of thinkers in these departments or the connections that exist between environmental and resource issues.

It is hard to attack environmental problems without running into resource and energy problems. As indicated, the biggest source of environmental degradation is the burning of fossil fuels to produce energy. A tax on fossil fuels would have many beneficial effects, from lowering pollution to reducing U.S. dependence on unstable sources of foreign supply. It also could help reduce the budget deficit, as many legislators now have discovered. Nonetheless, EPA has not been in a position to advocate a tax on energy consumption for any purpose other than pollution reduction, and the Energy Department has been similarly limited because of its restricted focus on energy. Neither government body has been able to draw the relevant implications from the connection between issues.

At the time of EPA's birth, no one anticipated that energy would so rapidly follow environmental protection as a cause of national concern. Rather, among EPA's designers (primarily lawyers and non-economists who considered themselves to be political realists), the dominant view was that there were very sound reasons for separating the environmental from natural resource programs. Avoiding conflicts of interest between developers and pollution control advocates was expressed as "keeping the fox out of the chicken coop."

Second, it may be argued that the retention of EPA's separate programs has limited EPA's abilities to deal comprehensively with broad, cross-program environmental challenges (such as developing global warming or cancer policies). Because EPA focuses on separate parts of the environment, it has not been able to exploit fully the obvious connections between environmental problems. Here the major reason for lack of change was not EPA's founders, who were basically sympathetic to the idea of integrated environmental management. Rather, Congress encouraged fragmentation by passing numerous environmental statutes and creating separate oversight structures for each of them. The incentive for Congress has been to enact more and different legislation in order to please voters in home districts. The incentive has not been to streamline agency operations or to get EPA officials to think broadly and comprehensively about environmental problems. No bill to broaden EPA's management options has ever received serious consideration from Congress. Rather, Congress micro-manages EPA in many respects by providing explicit instructions about what problems to address and when and how to address them. This micro-management by Congress severely constrains EPA from balancing the costs and benefits of its many activities and from coming up with a rational calculus of what it should and should not do.

Again in this instance, there was conscious intent to set up EPA in this fashion. However, the intent here did not come from EPA's founders but from Congress itself, which had suffered much criticism in the 1960s for not having paid adequate attention to pollution control. EPA's statutory legacy 
was a response to these criticisms. Congress spotted an issue that the public seemed to care passionately about (an issue that could decide elections) and latched onto it with remarkable tenacity. The result: perhaps no other regulatory agency in the federal government must administer so many separate laws with such differing and explicitly detailed requirements. Thus, EPA probably has less real discretion than most federal regulatory agencies.

Third, it may be argued that the creation of a single administrator of EPA has given this individual substantial discretionary powers to mold agency direction (subject to all the limitations previously mentioned) in many subtle and important ways. The power of the EPA administrator is much greater than the power of commissioners in comparable agencies such as NRC or FTC. This power can be exercised for better or worse, depending on the capabilities and perspective of the person holding this position.

The role of EPA administrators in molding agency policies is important beyond the scope of this already lengthy article. ${ }^{99}$ Nonetheless, the points made here about EPA's origins, and the influence of its structure on its policies have to be considered if EPA is to be reformed to serve national policy needs better.

99. See Mark Landy, Marc Roberts \& Stephen Thomas, The Environmental Protection Agency: Asking the IIrong Questions (Oxford U Press, 1990). 